\title{
Use of orthogonal functions in random regression models in describing genetic variance in Nellore cattle
}

\author{
Thiago Bruno Ribeiro da Silva ${ }^{1}$, Cláudio Vieira de Araújo², Thereza Cristina Borio dos \\ Santos Calmon de Bittencourt ${ }^{3}$, Simone Inoe Araújo ${ }^{2}$, Raysildo Barbosa Lôbo ${ }^{4}$, Luiz Antônio \\ Framartino Bezerra ${ }^{4}$, Delvan Alves da Silva ${ }^{5}$, Alessandra Alves da Silva ${ }^{5}$
}

\footnotetext{
1 Programa de Pós-Graduação em Ciência Animal - Universidade Federal de Mato Grosso - 78060-900 - Cuiabá, MT, Brazil.

${ }^{2}$ Instituto de Ciências Agrárias e Ambientais - Universidade Federal de Mato Grosso - Campus de Sinop - 78550-000 - Sinop, MT, Brazil.

${ }^{3}$ Departamento de Produção Animal - Escola de Medicina Veterinária - Universidade Federal da Bahia - 40000-000 - Salvador, BA, Brazil.

${ }^{4}$ ANCP - Associação Nacional de Criadores e Pesquisadores - Ribeirão Preto, SP, Brazil.

${ }^{5}$ Acadêmicos do Curso de Zootecnia da Universidade Federal de Mato Grosso, Campus de Sinop - 78550-000 - Sinop, MT, Brazil.
}

\begin{abstract}
A total of 204,912 records of birth weights up to 550 days of age, of 24,890 Nellore cattle, offspring of 375 sires and 16,917 dams from five herds in the state of Mato Grosso, Brazil, were used in order to describe the variability of the weight development by random regression models. The model evaluated as the most suitable used the covariance function of fourth order to describe the variability of the effects of additive genetic, animal permanent environmental and maternal effects of third order to describe the maternal genetic effect, with four classes of residual variance. Heritability estimates ranged from 0.18 to 0.46 from the beginning of trajectory to 210 days of age, from 0.45 to 0.48 post-weaning to 365 days of age and from 0.47 to 0.57 at later ages. The values of additive genetic correlations for different ages showed higher estimates between the closest ages, while birth weight was not very related to the weights at older ages. The body weight performance of the animals has additive genetic variation to respond to selection.
\end{abstract}

Key Words: beef cattle, live weight, selection

\section{Introduction}

The state of Mato Grosso, Brazil, has beef cattle as one of the strongest point of its economy, holding the largest effective herd among Brazilian states (IBGE, 2010).

Even with the numerical expression of Mato Grosso in the Brazilian livestock, there are few studies on the estimation of variance components or parameters for traits related to the performance of body weight in beef cattle, and neither are there studies on the adoption of random regression models involving only records of weight performance of Mato Grosso, so little is known about the behavior of the genetic variability of Nellore cattle in that state.

Traits correlated with the performance of body weight such as live weight at different ages may be considered with continuous variation over time. In this situation, some interest in the use of random regression models has been observed because these models describe the behavior of variance components along the growth line; they estimate and predict the parameters and genetic values anywhere on the growth line, in addition to identifying the phases of growth of the animal where there is the greatest genetic variability to trigger changes in the growth curve of the animals.
Furthermore, the use of random regression models allows for the accurate assessment to increase, since pre-adjustments such as age-standardized weights are not necessary and it is possible to use all the available information on weights and with the appropriate covariance (Meyer, 2005).

The use of random regression models in records of beef cattle is present in Cyrillo (2003), Mercadante et al. (2002), Nobre et al. (2003) and Sakaguti (2003) in the Nellore breed and also by Dias et al. (2006) in Tabapuã animals, all employing different degrees of adjustment for the covariance function in the description of the random effects of the models.

The objective of this study was to describe the genetic variability and to estimate genetic parameters for the body weight of the Nellore animals raised in the state of Mato Grosso, by using the random regression model identified as the most suitable.

\section{Material and Methods}

Records of information of weights from birth to 550 days of age of animals of Nellore breed, offspring of 375 
sires mated with 16,917 dams, resulting in 24,890 offspring from five herds in Mato Grosso state, participants of the Nellore Breeding Program - Nellore Brazil of the Brazilian Association of Farmers and Researchers were used in this study.

The birth months were grouped in two seasons: the dry season, which corresponded to the months of lowest rainfall, that is, from April to September and the rainy season, months of the highest rainfall (from October to March). Contemporary groups were generated comprising fixed effects of herd, year and season of birth and sex of the animal. The age of the cow at calving (average of $74.88 \pm 37.40$ months of age) was used as a covariable, adjusting to the linear and quadratic effects.

The random regression model used to obtain the fixed and random solutions adopted the Legendre polynomial function with different degrees, as follows:

$$
\mathrm{y}=X b+Z_{1} \alpha+Z_{2} \gamma+W_{1} \delta+W_{2} \rho+\varepsilon
$$

where $\mathrm{y}=$ vector of observations for the live weight of the animal at different ages; $b=$ vector of fixed effects that included parameters of fixed curve of the growth trajectory, the effect of contemporary group, in addition to the linear and quadratic effects of the cow at calving as covariable; $\alpha=$ random vector of genetic additive direct regression coefficients; $\gamma=$ random vector of mother genetic regression coefficients, $\delta=$ random vector of animal permanent environmental regression coefficients; and $\mathrm{p}=$ random vector of maternal permanent environmental regression coefficients; $\mathrm{X}, \mathrm{Z}_{1}, \mathrm{Z}_{2}, \mathrm{~W}_{1}$ and $\mathrm{W}_{2}$ are incidence matrices corresponding to $b, \alpha, \gamma$ and $p$, respectively. The assumptions associated with the model were defined as:

$$
\left[\begin{array}{l}
a \\
\gamma \\
\delta \\
p \\
\varepsilon
\end{array}\right] \sim N(0, V) ; V=\left[\begin{array}{ccccc}
K_{A} \otimes A & 0 & 0 & 0 & 0 \\
0 & K_{M} \otimes A & 0 & 0 & 0 \\
0 & 0 & K_{C} \otimes I_{N a} & 0 & 0 \\
0 & 0 & 0 & K_{Q} \otimes I_{N m} & 0 \\
0 & 0 & 0 & 0 & R
\end{array}\right]
$$

Where $\mathrm{K}_{\mathrm{A}}, \mathrm{K}_{\mathrm{M}}, \mathrm{K}_{\mathrm{C}}, \mathrm{K}_{\mathrm{Q}}$ = matrices of the coefficients of the covariance functions for the direct additive genetic, maternal genetic, animal permanent environmental effect and maternal permanent environmental effects, respectively; $\mathrm{A}=$ matrix of the relationship between individuals; $\mathrm{I}=$ an identity matrix; $\mathrm{Na}, \mathrm{Nm}=$ numbers of animals with records of live weight and number of mothers, respectively; and $\mathrm{R}=$ diagonal matrix containing the residual variances. The matrix of the numerators of inbreeding coefficients (NRM) used in the analyses was obtained from the file with pedigree containing 50,540 different animals.

The Legendre polynomial degree used in the functions of covariance for description of fixed average curve setting as well as in the description of the random effects of the model ranged from one (equivalent to the simple model of repeatability) to five. Classes of residual variance were composed ranging from one (homogeneous residue) to six (heterogeneous residual variances), arranged as follows: from birth to 60 days; 61-120 days; 121-200 days; 201-300 days; 301-400 days; and from 401 to 540 days of age.

The comparison between models with polynomial degrees and with different residual classes was performed using the Akaike Information Criterion (AIC) (Wolfinger, 1993).

\section{Results and Discussion}

The results for the values of the Akaike Information Criterion ranged from 357,221.90 (for the model that considered only the first Legendre polynomial) to $298,482.40$ for the model considered the most appropriate to describe the genetic and environmental variability of the line of weight development of the animals, i.e., the model that used covariance function of fourth polynomial order to describe the variability of direct genetic random, animal permanent environmental and maternal permanent effects and also with function of covariance of the third polynomial order to describe the variability of the maternal genetic effect and residual variance from four classes. Classes of residual variances were composed of periods from birth to 60 days $\left(15.40 \mathrm{~kg}^{2}\right) ; 61$ to 200 days $\left(61.34 \mathrm{~kg}^{2}\right) ; 201$ to 300 days $\left(214.87 \mathrm{~kg}^{2}\right)$; and 301 to 540 days of age $\left(321.46 \mathrm{~kg}^{2}\right)$.

The results show that the description of variation of random additive genetic and environmental effects are more complex, since they overcome changes throughout the trajectory, requiring polynomials of higher degree, when compared with the variation of the maternal genetic effect.

Santoro et al. (2005) found that the best model presented covariance functions with degree five, but with homogeneous error.

Estimates of components of direct additive genetic, animal permanent environmental and phenotypic variances (Figure 1) showed very similar behavior patterns, characterized by increased variance with the advance in age, especially in post weaning.

Estimates of variance for maternal genetic and maternal permanent environmental effects presented increase before 205 days of age, remaining practically constant at older ages (Figure 2).

The variances concerning these random effects contributed little in magnitude to the composition of the total variance, indicating little influence of the maternal effect on the variability of the weight in the offspring. Greater variation of the maternal genetic effect is observed during 


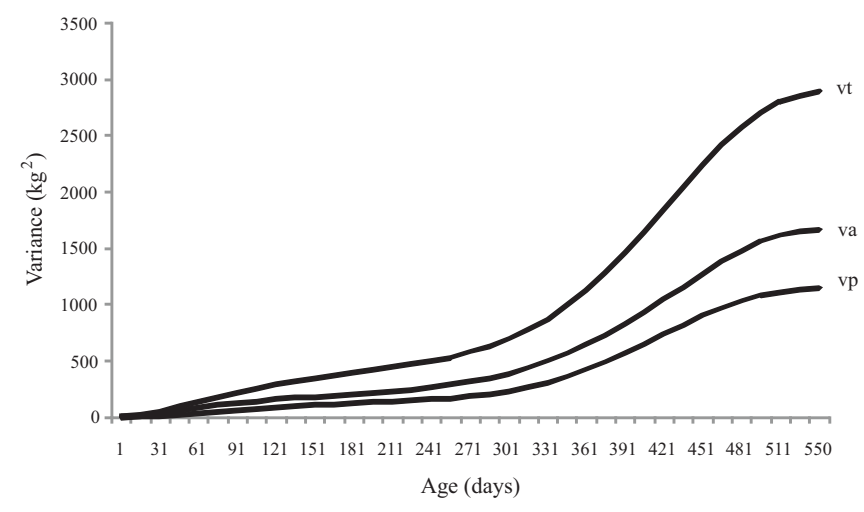

Figure 1 - Direct additive genetic (va), animal permanent environmental (vp) and phenotypic (vt) variances throughout growth trajectory of the animals.

suckling, remaining with larger and constant variances in the post-weaning. Behaviors similar to the pattern of direct additive genetic and maternal variances and animal permanent environmental and maternal covariances were observed by Albuquerque \& Meyer (2001), Nobre et al. (2003) in Nellore breed and by Dias et al. (2006) in Tabapuã breed.

The variance from the animal permanent environmental effect exhibited behavior similar to direct additive genetic variance, indicating that the repeatability of body weight is high. On the other hand, the maternal permanent environment effect had little influence on the variability of the growth trajectory of the animals. A contributing cause for this behavior is the low number of offspring per mother, which makes the estimation of this component along the growth trajectory of the animals a difficult task.

The variance estimates of the temporary environment, arranged in four classes, clearly indicated the distribution of that effect throughout the development of weight at birth, weaning, weaning year and yearling year, confirming the presence of heterogeneity of variances along the trajectory. Major variances of this effect were observed for the weights at older ages, but with higher estimates of additive genetic variance, providing increased heritability estimates at these ages.

The consequence of the behavior of the variances of random effects (Table 1) reflects moderate heritability estimates from birth until the age of pre-weaning ( 0.18 to $0.22)$, with moderate to high values of heritability estimates of weight from weaning to 365 days of age ( 0.21 to 0.48 ) and high heritability estimates of weight from 365 to 550 days of age ( 0.47 to 0.58$)$, similar to the behavior observed for the direct additive genetic variance.

It can be inferred from the estimates obtained for direct heritability that there was a necessary and sufficient additive genetic variability for achieving a significant genetic gain

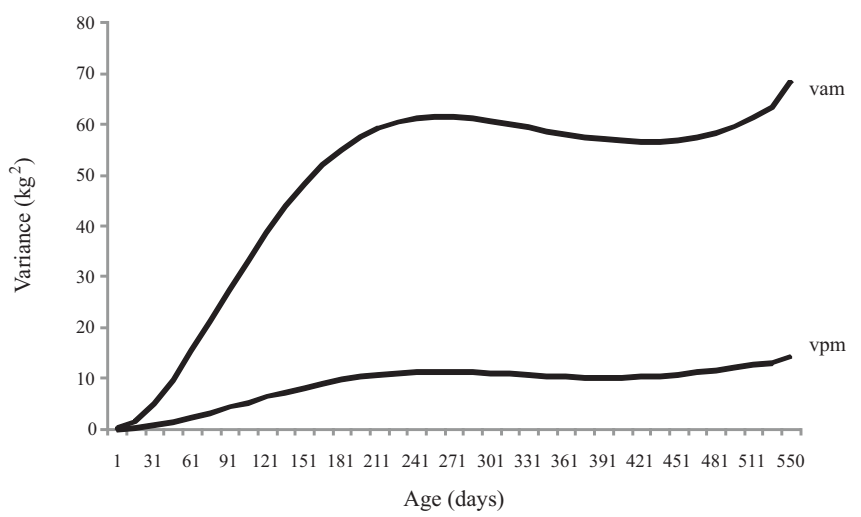

Figure 2 - Maternal additive genetic (vam) and maternal permanent environmental (vpm) variances throughout growth trajectory of the animals.

when the selection is made based on information from the individual itself of age at weaning.

Cyrillo (2003) also observed a lower heritability estimate at the beginning of the growth path with higher estimates at yearling ( 0.09 and 0.40 , respectively). Nobre et al. (2003) estimated heritability in Nellore ranging from 0.14 (birth) to 0.27 (683 days of age), with similar estimates obtained by Santoro et al. (2005), also in Nellore and by Dias et al. (2006) in Tabapuã breed. Opposite behavior was observed by Valente et al. (2008) with higher heritability estimates for weight at 90 days of age (0.33) and the lowest estimates ( 0.12 to 0.16$)$ after 250 days of age.

The estimates of heritability indicate good accuracy for a favorable selection to weight performance of animals from weaning to yearling. High heritability at such ages associated with the high phenotypic standard deviations show good responses of genetic gain at these ages.

The maternal heritability estimates showed low values during suckling, becoming practically zero at other ages, suggesting low efficiency in selection for increased maternal ability.

The estimates obtained in this study indicate increasing maternal influence up to 210 days of age. Therefore, despite the low magnitude, greater response to selection for maternal ability can be expected with the selection made based on weights obtained close to weaning.

Table 1 - Estimates of direct $\left(\mathrm{h}^{2}\right)$ and maternal heritability $\left(\mathrm{h}_{\mathrm{m}}{ }_{\mathrm{m}}\right)$ for weight of Nellore animals at different ages

\begin{tabular}{lcl}
\hline Age (days) & $\mathrm{h}^{2}$ & $\mathrm{~h}_{\mathrm{m}}^{2}$ \\
\hline 1 & 0.20 & 0.01 \\
120 & 0.45 & 0.11 \\
210 & 0.46 & 0.12 \\
365 & 0.48 & 0.04 \\
450 & 0.56 & 0.03 \\
550 & 0.57 & 0.02 \\
\hline
\end{tabular}


It is important to consider that selection for maternal ability should result in females with higher genetic potential for milk production, because this trait is the main component of maternal effects (Hohenboken, 1985). Attention should be drawn to the fact that there is antagonism between milk production and deposition of muscle tissue in the carcass. Thus, exacerbated selection for maternal ability leads to negative effects on growth rate, besides favoring the increase in energy requirements for maintenance of the matrices.

Similar behavior was verified by Cabrera et al. (2001). On the other hand, higher maternal heritability estimates for yearling weights from birth were observed by Nobre et al. (2003).

The values of additive genetic correlations for body weight at different ages in the growth trajectory of the animals (Table 2) show major genetic associations between the closest ages, while the birth weight appeared not to be very correlated with the weights at other ages, which is interesting from an economic point of view, since it is desirable to maintain the average weight at birth near the average value stipulated for the breed. Thus, selection for increased weight at weaning or yearling would not lead to unfavorable correlated responses regarding the selection of bulls for facilitating calving.

In general, selection for a particular weight during or after weaning would cause positive response on weight gain at other ages.

There was an overlapping behavior with the largest value of eigenvalue associated with the first eigenvector from the matrix of random regression coefficients of the direct additive genetic effect, which alone accounted for about $90 \%$ of the total variation, indicating that the selection made for weight gain at any ages is the same as raising the weight in all other ages. Behavior similar to that was found in Meyer (2003).

Santoro et al. (2005) also found low genetic correlations between weight in early ages and weight at the final ages in the growth trajectory.

Table 2 - Phenotypic correlations (above the diagonal) and additive genetic correlations (below the diagonal) for weights of animals at different ages (days)

\begin{tabular}{lllllll}
\hline \multirow{2}{*}{ Ages } & \multicolumn{7}{c}{ Ages } \\
\cline { 2 - 7 } & 1 & 120 & 210 & 365 & 450 & 550 \\
\hline 1 & & 0.35 & 0.37 & 0.33 & 0.33 & 0.27 \\
120 & 0.34 & & 0.87 & 0.64 & 0.61 & 0.59 \\
210 & 0.28 & 0.96 & & 0.73 & 0.67 & 0.68 \\
365 & 0.31 & 0.85 & 0.90 & & 0.93 & 0.86 \\
450 & 0.32 & 0.80 & 0.82 & 0.98 & & 0.95 \\
550 & 0.25 & 0.76 & 0.78 & 0.94 & 0.97 & \\
\hline
\end{tabular}

Positive to high genetic correlations between weights at weaning and yearling were also found by Nobre et al. (2003), Santoro at al. (2005) and Valente et al. (2008).

The genetic correlation estimate between weaning weights at 550 days of age were high and positive and indicate that most of the genes responsible for higher weights at these ages are the same.

\section{Conclusions}

The use of regression models with Legendre polynomials of order five to describe direct additive genetic, animal permanent environmental and maternal permanent effects and of order four to describe maternal genetic effect satisfactorily describe the changes in the variances of the weights from birth to 550 days of age in Nellore cattle in the state of Mato Grosso, Brazil. The use of heterogeneity of residual variances arranged in four classes is more appropriate to model the longitudinal data of the growth of the animals. Selection for heavier weights at weaning promotes increases in the later ages up to 550 days of age.

\section{References}

ALBUQUERQUE, L.G.; MEYER, K. Estimates of covariance functions for growth from birth to 630 days of age in Nellore cattle. Journal of Animal Science, v.79, n.11, p.2776-2789, 2001.

CABRERA, M.E.; GARNERO, A.V.; LÔBO, R.B. et al. Efecto de la incorporación de la covarianza genética directa-materna em el análisis de características de crecimiento em la raza Nellore. Livestock Research for Rural Development, v.13, n.3, 2001. Available at: $<$ http://www.lrrd.org/lrrd13/3/cont133.htm > Accessed on: Oct. 15, 2009.

CYRILLO, J.N.S.G. Estimativas de funções de covariância para o crescimento de machos Nelore utilizando modelos de regressão aleatória. 2003. 72f. Tese (Doutorado em Produção Animal) Universidade Estadual Paulista, Jaboticabal.

DIAS, L.T.; ALBUQUERQUE, L.G.; TONHATI, H. et al. Estimação de parâmetros genéticos para peso do nascimento aos 550 dias de idade para animais da raça Tabapuã utilizando-se modelos de regressão aleatória. Revista Brasileira de Zootecnia, v.35, n.5, p.1915-1925, 2006.

HOHENBOKEN, W.D. Genetic structure of population. 7. Maternal effects. In: CHAPMAN, A.B. (Ed.) General and quantitative genetics. Amsterdan: Elsevier, 1985. p.135-146.

INSTITUTO BRASILEIRO DE GEOGRAFIA E ESTATÍSTICA - IBGE. Diretoria de Pesquisas, Coordenação de Agropecuária, Pesquisa da Pecuária Municipal 2009-2010. Tabela 1 - Efetivo dos rebanhos em 31.12 e variação anual segundo as categorias - Brasil - 2009-2010. 2010. Available at: <http://www.ibge. gov.br/home/presidencia/noticias/noticia_visualiza.php?id noticia=1830\&id_pagina=1>. Accessed on: Feb. 12, 2011.

MERCADANTE, M.E.Z.; PACKER, I.U.; RAZOOK, A.G. et al. Dias ao parto de fêmeas Nelore de um experimento de seleção para crescimento. II - Modelo de regressão aleatória. Revista Brasileira de Zootecnia, v.31, n.4, p.1726-1733, 2002.

MEYER, K. Random regression models for analyses of longitudinal data in animal breeding. In: Proceedings 54th Session of the International Statistical Institute, 2003, Berlin. Proceedings... Berlin: ISI, 2003. (CD-ROM). 
MEYER, K. Estimates of genetic covariance functions for growth of Angus cattle. Journal of Animal Breeding and Genetics, v.122, p.73-85, 2005.

NOBRE P.R.C.; MISZTAL I.; TSURUTA S. et al. Analyses of growth curves of Nellore cattle by multiple-trait and random regression models. Journal of Animal Science, v.81, p.918-926, 2003.

SAKAGUTI, E.S.; SILVA, M.A.; QUAAS, R.L. et al. Avaliação do crescimento de bovinos jovens da raça Tabapuã, por meio de análises de funções de covariâncias. Revista Brasileira de Zootecnia, v.32, n.4, p.864-874, 2003.
SANTORO, K.R.; BARBOSA, S.B.P.; SANTOS, E.S. et al. Uso de Funções de Covariância na Descrição do Crescimento de Bovinos Nelore Criados no Estado de Pernambuco. Revista Brasileira de Zootecnia, v.34, n.6, p.2290-2297, 2005 (supl.).

VALENTE, B.D.; SILVA, M.A.; SILVA, L.O.C. et al. Estruturas de covariância de peso em função da idade de animais Nelore das regiões Sudeste e Centro-Oeste do Brasil. Arquivo Brasileiro de Medicina Veterinária e Zootecnia, v.60, n.2, p.389-400, 2008.

WOLFINGER, R.D. Covariance structure in general mixed models. Communications in Statistics, v.22b, p.1079-1106, 1993. 